\title{
PENGEMBANGAN GAME KETEPATAN DADU MATEMATIKA SEBAGAI PENGUAT MOTIVASI BELAJAR SISWA KELAS 2 SEKOLAH DASAR
}

\author{
Farah Ghina Sabrina, Eka Pramono Adi, Henry Praherdhiono \\ Jurusan Teknologi Pendidikan, Fakultas Ilmu Pendidikan, Universitas Negeri Malang \\ Jalan Semarang 5 Malang 65145 0341-574700 \\ Farah.ginuk@gmail.com
}

\section{Article History}

Received: 18 Agustus 2020, Accepted: 6 November 2020, Published: 26 Februari 2021

\begin{abstract}
Abstrak
Penelitian ini bertujuan untuk menghasilkan produk dan menjelaskan keadaan meningkatnya motivasi belajar melalui game ketepatan dadu pada siswa kelas II. Jenis penelitian yang digunakan dalam penelitian yang dikembangkan Borg and Gall. Produk game ketepatan dadu matematika yang akan dikembangkan meliputi : Papan yang berbentuk persegi atau wadah yang terdapat penutupnya; Buku petunjuk yang berisi cara penggunaan dan peraturan bermain dan materi yang berisi materi tentang matematika bab konverensi panjang, berat.. Data yang telah diuji cobakan motivasi siswa tersebut ini, secara keseluruhan dapat dikatakan siswa termotivasi baik dalam penggunaan media permainan. Berdasarkan hasil ini pengolahan data dan kriteria yang telah ditentukan, dapat diketahui bahwa media Permainan Ketepatan Dadu Matematika yang dikembangkan termasuk dalam kriteria layak dan mendapatkan motivasi yang bagus dalam menggunakan media ini.
\end{abstract}

Keyword: Game Ketepatan Dadu, Motivasi Belajar, Matematika

\begin{abstract}
This study aims to produce a product and explain the state of increasing learning motivation through the precision dice game for grade II students. The type of research used in the research developed by Borg and Gall. The precision dice math game products to be developed include: A board with a square shape or a container with a lid; The manual which contains how to use and play rules and material that contains material on mathematics in a long, heavy convention chapter. The data that has been tested on this student's motivation, overall it can be said that students are well motivated in the use of game media. Based on these results, data processing and predetermined criteria, it can be seen that the developed Mathematics Dice Accuracy Game media is included in the appropriate criteria and gets good motivation in using this media.
\end{abstract}

Keyword: Motivation to Learn; Mathematics. 


\section{PENDAHULUAN}

Adanya wabah covid-19 menjadi tantangan awal baru yang mengharuskan siswa belajar di rumah dan mengasah kreativitas guru untuk merancang pembelajaran. Pemberian tugas dan materi tambahan juga menjadi cara agar anak rajin belajar. Namun ditemukan perbedaan antara siswa laki-laki dan perempuan seperti temuan dari (Feng, 2016) bahwa saat memeriksa data interaksi sistem-siswa, kami menemukan perbedaan yang signifikan antara anak laki-laki dan perempuan dalam perilaku mencari bantuan. Demikian itu, kami menemukan bahwa anak laki-laki memiliki mendapat manfaat dari intervensi pekerjaan rumah online lebih dari anak perempuan. Berbagai cara dilakukan di masa pandemi, (Ichinose, 2016) telah menguji keterkaitan matematis siswa keyakinan dalam kursus matematika online. Beliau menyarankan bahwa pembelajaran online dapat menjadi mode yang efektif atau tidak efektif belajar matematika tergantung dari pengalaman dan harapan dari masing-masing siswa. Informasi ini dapat membantu menginformasikan pengajaran dan pembelajaran matematika di tingkat sekunder dan pasca sekolah menengah.

Belajar ialah suatu cara kegiatan atau suatu proses yang dapat memperoleh pengetahuan, meningkatkan ketrampilan, memperbaiki perilaku, sikap, dan mengokohkan kepribadian (Suyono \& Hariyanto, 2011). Maka perlu adanya inovasi dalam pembelajaran matematika. (Israel, 2015) dalam penelitiannya menemukan bahwa inovasi matematika, lokasi, jenis kelamin dan teknologi mempengaruhi kinerja akademik siswa pada pelajaran matematika. kondisi pendidik juga perlu diperhatikan. Belajar matematika juga bisa dilakukan dengan media-media yang biasa digunakan siswa untuk bermain, seperti penelitian dan pengembangan yang dilakukan oleh (Handoko, 2017) tentang media pembelajaran matematika berupa media Play Dough (atau dalam penyebutan di Indonesia yaitu plastisin) Badut (Bangun Datar Sudut) pada materi menghitung jumlah sudut segi banyak.

Tidak dalam permainan modern saja, namun peneliti sebelumnya juga telah mengembangkan permainan tradisional untuk merancang pembelajaran matematika siswa. (Muzdalipah, 2015) telah mengembangkan penelitian dan pengembangan yang bertujuan untuk mengungkap potensi etnomatematika yang bisa mengembangkan menjadi permainan tradisional masyarakat Kampung Naga menjadi proses pembelajaran matematika yang dapat diterapkan pada pembelajaran SD. Congklak ini terdapat versi operasi hitung dan modulo peluang dan pengurangan dan penjumlahan. Rendahnya motivasi yang terdapat pada siswa dalam belajar dapat menurunkan prestasi belajar yang dapat dilihat dari rendahnya aktivitas belajar dan hasil belajar yang belum mencapai KKM. Permasalahan tersebut dapat diatasi dengan model seperti yang telah diteliti oleh (Cahyadi dkk, 2019). (Kanprao, C., \& Naeprakhon, W, 2020) menurutnya penelitian tentang penggunaan media permainan ular tangga untuk meningkatkan ketrampilan membaca bahas Thailan, merupakan penelitian eksperimental dengan tujuan membandingkan.

Penelitian serupa yang berusaha untuk meningkatkan motivasi belajar siswa juga dilakukan oleh (Suwarni, 2016) yang menunjukkan bahwa peningkatan minat, motivasi dan prestasi belajar siswa dengan menggunakan media gambar. Jadi, media gambar adalah media yang dipergunakan untuk menvisualisasikan atau menyalurkan pesan dari sumber ke penerima (siswa). Dalam pengguna media gambar dalam proses kegiatan pembelajaran akan memberikan hasil belajar yang optimal jika digunakan secara tepat. Terdapat beberapa cara untuk meningkatkan motivasi belajar matematika pada siswa. (Ufer, 2013) keterampilan dalam memprediksi perolehan pembelajaran matematika di usia sekolah di luar status sosial ekonomi orang tua, tetapi juga diperlukan untuk mengontrol ukuran status sosial ekonomi saat mempelajari hubungan antara keterampilan bahasa dan pembelajaran matematika. Beberapa penelitian juga telah mengembangkan beberapa cara dalam permainan untuk mengatasi hal tersebut, diantaranya (Fatoni, 2016) yang meneliti tentang Peningkatan Motivasi Belajar Matematika Melalui Strategi Team Game Tournament Dengan Media Cartoon Game Pada Siswa Kelas 2 MI Muhammadiyah Program Khusus Kartasura Tahun Ajaran 2015/2016. Hasil penelitian menunjukkan adanya peningkatan motivasi belajar matematika. Dapat disimpulkan bahwa dengan penerapan strategi 
dengan media Tournament Team Game Cartoon Games dapat meningkatkan motivasi belajar matematika pada siswa kelas 2 .

Produk pengembangan yang di hasilkan adalah permainan ular tangga (ketepatan dadu) untuk melatih berhitung anak pada pembelajaran matematika dengan spesifikasi produk yang dikembangkan sebagai berikut: Media permainan ular tangga berhitung untuk kelas II SD akan di cetak dengan bentuk kotak atau persegi, selanjutnya media permainan ular tangga ini dilengkapi dengan kartu soal yang terdapat pada papan permainan ular tangga. Kartu jawaban terdapat pada lembar yang telah disediakan, terdapat 3 kartu dalam permainan yaitu; kartu soal, kartu motivasi, dan kartu soal dengan tingkatan mudah dan sulit, kemudian semua jawaban dan kartu soal siswa diminta untuk langsung menjawab pertanyaan yang didapat pada kartu soal tersebut, Pada bagian belakang papan permainan, terdapat petunjuk permainan yang perlu dibaca terlebih dahulu sebelum melakukan permainan. matematika merupakan salah satu kompetensi terpenting yang diajarkan di sekolah. Untuk meningkatkan keterampilan matematika anak-anak (Fischer, 2013) intervensi dan pelatihan yang terdapat dalam pembelajaran matematika uraian berbagai tingkat kemahiran dengan kelompok usia berbeda, dalam pengaturan yang berbeda, dapat lebih fokus pada satu tugas atau serangkaian tugas yang berbeda, diterapkan untuk durasi yang berbeda, dan menangani jenis yang berbeda.

Dari hasil pengamatan penelitian yang dilakukan, siswa di SD mengalami kesulitan dalam berhitung, siswa kurang berminat dalam berhitung karena motivasi siswa untuk berhitung dengan baik dan benar masih kurang dan dalam pembelajaran yang berkaitan dengan berhitung, guru belum pernah menerapkan pembelajaran dengan menggunakan permaian ular tangga. Adanya permasalahan tersebut, maka produk yang dikembangkan permainan untuk memotivasi siswa belajar matematika. Tujuan dari penelitian dan pengembangan ini untuk menghasilkan produk dan menjelaskan peningkatan motivasi belajar melalui game ketepatan dadu pada siswa kelas II Sekolah Dasar.

\section{METODE}

Jenis metode yang digunakan ini adalah Penelitian dan Pengembangan (R\&D) yang dikembangkan Borg and Gall. Tahapan menggunakan langkah-langkah penelitian menurut Borg and Gall ada 10 langkah metode pelaksanaan strategi dan pengembangan, namun saat ini telah mengadaptasi tahapan menjadi 7 tahap. Dalam kondisi saat ini mengadaptasi menjadi 7 tahap karena agar dapat disesuaikan dengan keadaan di lapangan, keterbatasan waktu, tenaga dan biaya, dan dalam keadaan saat ini terjadinya pandemi covid-19 yang tidak memungkinkan penelitian melakukan semua tahapan dari model Borg and Gall. Penelitian ini juga tidak melakukan uji coba lapangan secara menyeluruh dikarenakan sekolah juga melakukan pembelajaran secara daring, maka dari itu adaptasi model ini disesuaikan dengan keadaan yang terjadi pada saat ini.

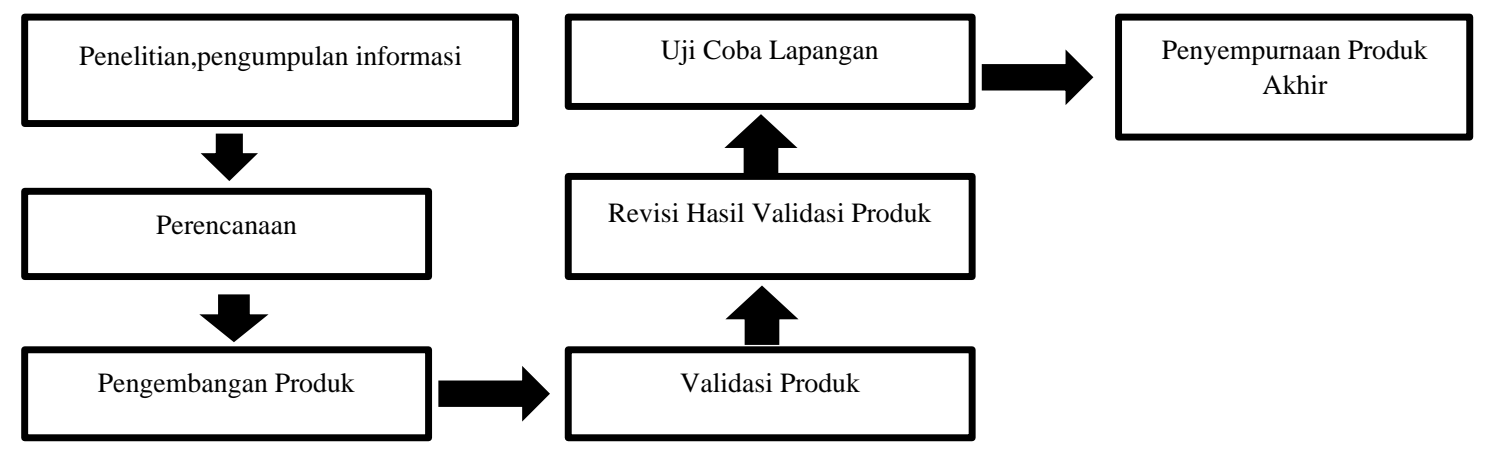

Gambar 1. Metode Borg and Gall (Sukmadinata, 2013)

Subjek yang terdapat pada uji coba terbatas yakni satu orang guru SD dan sepuluh siswa SD Mutiara Umat Tulungagung. Hasil uji coba terbatas, produk direvisi. Hasil revisi produk dalam uji coba terbatas dapat digunakan dalam uji coba pemakaian, subjek dalam uji coba pemakaian yaitu satu guru dan 5 siswa SD. Dalam penelitian dan pengembangan ini, instrumen pengumpulan data menggunakan 
kuisioner atau angket dan dokumentasi berupa foto atau gambar. Angket atau kuisioner ini digunakan untuk memperoleh data berupa kelayakan produk dengan berbagai aspek yang telah terpilih. Selain data yang berupa kuisioner instrumen pengumpulan data yang digunakan dalam penelitian dan pengembangan ini yakni observasi dan wawancara singkat dengan melihat kondisi disekolah. Data obervasi yang diperoleh ialah berupa foto siswa saat menjalani proses pembelajaran kemudian ketika melakukan uji penggunaan media. Terlihat siswa antusias dan bersemangat melakukan proses pembelajaran menggunakan media permainan. Dalam penelitian ini juga mendapatkan tingkat motivasi yang meningkat dengan penggunaan media permainan ular tangga ini. terdapat tiga jenis penyebaran intrumen yaitu instrumen ahli media yang memberikan tanggapan atau saran terhadap hasil produk permainan ular tangga, selanjutnya terdapat instrumen ahli materi yang memberikan masukan saran terhadap materi yang akan di berikan oleh siswa dalam permainan ular tangga tersebut, terakhir terdapat instrumen motivasi siswa yaitu untuk mengetahui seberapa termotivasinya siswa dalam proses pembelajaran matematika menggunakan media permainan ular tangga.

Jenis data yang dikumpulkan pada penelitian dan pengembangan adalah data kuantitatif dan data kualitatif. Pengumpulan data yang diambil menggunakan metode observasi dan angket. Angket instrumen untuk ahli materi sebanyak 50 soal pertanyaan. Angket instrumen untuk ahli media sebanyak 50 soal pernyataan. Angket instrumen untuk siswa sebanyak 40 soal pernyataan. Aspek yang diuji pada instrumen ini adalah aspek fisik, aspek isi/konten, dan aspek kebahasaan. Instrumen yang digunakan menggunakan rating scale dengan interval (Setuju (4), Cukup Setuju (3), Kurang Setuju (2), Tidak Setuju (1)). Tingkat layak yang digunakan untuk media permainan ini berdasarkan tingkat kelayakan dan kevalidan menurut Arikunto (2006).

Subjek pada penelitian ini adalah siswa kelas 2 Sekolah Dasar. Dikarenakan pandemi covid-19 penelitian ini hanya mengambil 5 siswa kelas 2 Sekolah Dasar. Dalam penelitian dan pengembangan ini data yang dianalisis dalam penelitian dan pengembangan ini terdiri dari data kualitatif dan data kuantitatif. Teknik analisis kualitatif diperoleh dari pembagian angket atau kuisioner dan wawancara dengan satu ahli materi dan satu ahli media. Digunakan untuk menganalisis kritik, saran, dan pendapat dari validasi ahli media, ahli materi, dan siswa. Analisis kualitatif dalam hal ini berupa gambaran mengenai objek penelitian, dan data kualitatif memberikan dan menunjukkan kualitas objek yang akan dilakukan. Data kuantitatif ini merupakan data yang berupa angka dan diperoleh pada saat melakukan uji coba kelompok kecil dan besar. Analisis kuantitatif untuk (1) Mengukur Peningkatan Motivasi Belajar Siswa menggunakan angket motivasi belajar siswa menggunakan rating scale dianalisis Instrumen dengan menggunakan interval jawaban (Setuju (4), Cukup Setuju (3), Kurang Setuju (2), Tidak Setuju (1)). Tingkat layak yang digunakan untuk penilaian media permainan ini berdasarkan tingkat kelayakan produk menurut Arikunto (2006). (2) Kelayakan Media Pembelajaran Ular Tangga Matematika.

\section{HASIL}

Hasil penelitian dan pengembangan ini akan dipaparkan hasil produk pengembangan berupa Permainan Ketepatan Dadu (Ular Tangga Matematika) dengan tampilan yang didesain agar siswa kelas 2 dapat tertarik ke dalam permainan dan juga warna dalam desain dapat membuat siswa termotivasi untuk lebih giat dalam proses belajar matematika, terdapat bagian permainan ular tangga dan terdapat soal-soal yang disediakan didalam permaianan dan akan dijawab oleh peserta yang akan melakukan permaian ketetapan dadu matematika ini, terdapat 2 tingkatan soal dalam permainan yaitu tingkat mudah dan sulit. Dan juga terdapat materi motivasi yang berisi materi-materi. Semua jawaban dan kartu soal siswa diminta untuk langsung menjawab pertanyaan yang didapat pada kartu soal tersebut, sedangkan jika salah siswa akan mendapat hukuman berupa mundur 2 langkah kotak tetapi jika benar siswa atau pemain akan tetap melanjutkan perjalanan bermainan seperti biasa. Penelitian ini melihat motivasi siswa dalam belajar matematika ini sudah baik dan siswa senang dengan adanya proses belajar menggunakan 
media permainan ular tangga ini, siswa dapat dengan mudah mengerjakan dan merasa menyenangkan belajar sambal bermain. Indikator siswa memiliki Motivasi Belajar yang tinggi ditandai dengan adanya hasrat dan keinginan berhasil, dorongan dan kebutuhan dalam belajar, harapan dan cita-cita masa depan, penghargaan dalam belajar, kegiatan yang menarik dalam belajar, dan lingkungan belajar yang kondusif sehingga memungkinkan seorang siswa dapat belajar dengan baik. Hasil uji coba dilakukan pada kelas 2 SD berjumah 5 orang, dikarenakan situasi saat ini sedang adanya pandemi virus covid-19. Penelitian ini hanya mendapatkan 5 siswa saat ini, karena sekolah sedang melakukan proses belajar dengan jarak jauh. Setelah dilakukan uji coba produk (penggunaan) maka ditentukan data hasil dari instrumen angket tentang motivasi belajar siswa menggunakan media Permainan Ketetapan Dadu.

\section{Penyajian Data dan Hasil Analisis Ahli Media}

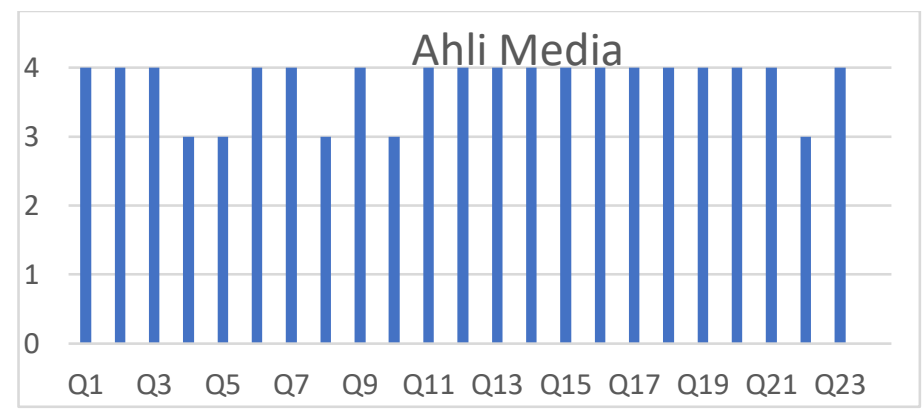

Gambar 2. Hasil Kelayakan Ahli Media

Hasil review ahli media mendapatkan hasil keseluruhan nilai sebesar 94,56\%. Dari seluruh pertanyaan terdapat 18 pernyataan dengan nilai 4, dan 5 pernyataan dengan nilai 3 seperti yang terlihat pada gambar 2. Sehingga produk hasil kembangan dinyatakan layak untuk digunakan. Ahli media memberikan komentar bahwa keseluruhan media permaian sudah bagus.

\section{Penyajian Data dan Hasil Analisis Ahli Materi}

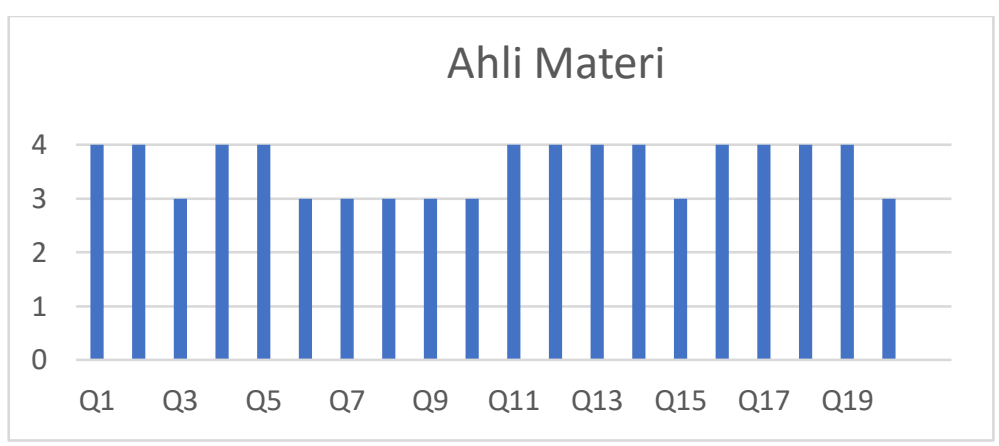

Gambar 3. Hasil Kelayakan Ahli Materi

Hasil review ahli materi mendapatkan keseluruhan bahwa hasil yang diperoleh adalah 90\%. Dari seluruh pertanyaan terdapat 12 pernyataan dengan nilai 4, dan 8 pernyataan dengan nilai 3 seperti pada gambar 3. Sehingga produk hasil kembangan dinyatakan layak untuk digunakan. Ahli materi memberikan komentar media permainan ini sudah bagus dan materi telah sesuai.

\section{Penyajian dan Analisis Data Uji Coba Motivasi Siswa}

Berdasarkan pengolahan data uji coba motivasi siswa tersebut, seperti gambar 4 diatas. Secara keseluruhan dapat diperoleh hasil $85,05 \%$. Berdasarkan hasil pengolahan data dan kriteria yang telah ditentukan, diketahui bahwa media Permainan Ketepatan Dadu Matematika yang dikembangkan termasuk dalam kriteria tinggi dan mendapatkan motivasi yang bagus dalam menggunakan media ini. Uji coba motivasi siswa melibatkan 4 siswa. Beberapa siswa menyampaikan pendapatnya bahwa media permainan ini sudah bagus, materi dan evaluasi sudah jelas, dan siswa merasa termotivasi untuk belajar matematika. 


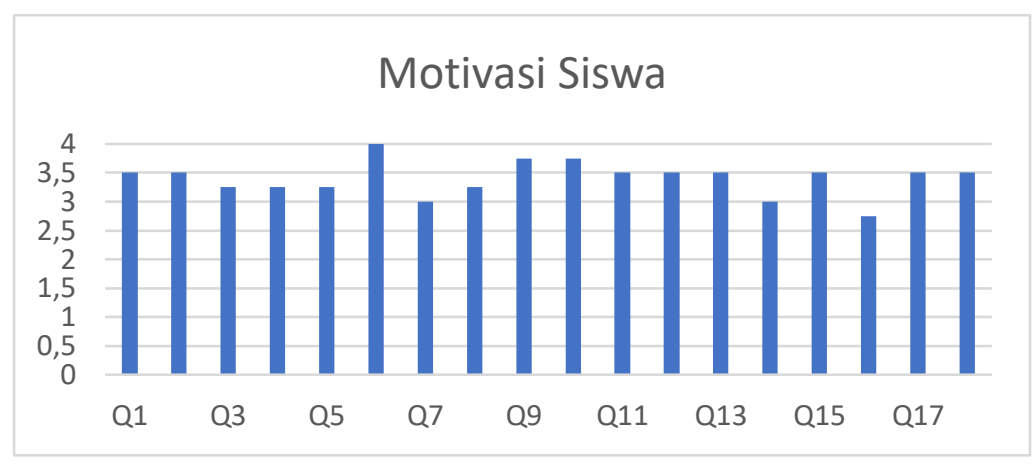

Gambar 4. Data Motivasi siswa

\section{Revisi Produk}

Berdasarkan angket yang di berikan kepada ahli media, serta wawancara yang dilakukan, ahli media memberikan saran untuk memperbaiki dalam hal petunjuk yang jelas dengan menggunakan bahasa siswa kelas 2 dan perlu ada reward dan punismend. Berdasarkan angket yang diberikan kepada ahli materi, serta wawancara yang dilakukan, ahli materi memberikan saran berupa pemahaman dengan tujuan pembelajaran disesuaikan, kegiatan inti berdasarkan dengan tujuan pembelajaran. Berdasarkan angket yang diberikan kepada siswa serta wawancara yang dilakukan, mendapatkan tanggapan atas media permainan yang secara luas sudah menarik dan dapat dipahami oleh penggunan. Selain itu setelah menggunakan permainan ketepatan dadu matematika ini siswa juga merasa termotivasi untuk belajar.

\section{PEMBAHASAN}

Media bermain ini bisa dimainkan menggunakan papan dan bermain bersama namun memainkanya perorangan dalam kegiatan pembelajaran. Kegiatan bermain ini memberikan daya berfikir anak pada penguatan dalam hal bermain namun juga masih dalam belajar, dalam kegiatan ini disajikan gambar-gambar agar siswa tertarik dan mengerjakan latihan soal yang disediakan. Terdapat juga hukuman dan hadiah jika tidak tepat ataupun kebenaran dalam menjawab dan bermaian dengan ketepatan dadu. Sehingga peserta didik mendapatkan motivasi dalam permainan ini.

Uraian kriteria kelayakan, aspek hasil dari ahli media memperoleh kualifikasi layak. Aspek yang diperoleh dari kedelapan aspek tersebut diantaranya Ketepatan memilih alat untuk pengembangan, Kejelasan petunjuk penggunaan media, Komunikatif, Pemilihan jenis huruf yang digunakan, dan desain rapi. Hal ini perlu diperhatikan karena dapat menstimulus aspek perkembangan yang lain, menurut (Nurhasanah, 2017) bahwa mengidentifikasi kelebihan dan kekurangan aplikasi permainan dadu dalam kegiatan bahasa inggris dapat meningkatkan penguasaan kosa kata. Hasil penelitian tersebut menunjukkan permainan dadu aplikasi meningkatkan penguasaan kosakata pelajar muda dan beberapa kelebihan dan kekurangan aplikasi permainan dadu di meningkatkan penguasaan kosakata pelajar muda dalam proses pembelajaran bahasa Inggris. Komunikatif sangat berpengaruh untuk siswa pada pembelajaran, hal ini diteliti oleh (Strohmyer, 2016) yang menunjukkan peningkatan pemikiran kritis terkait dengan keduanya dan kemampuan peserta didik dalam mengatur pembelajaran sendiri. Konsep kolaborasi rekan bergeser sebagai siswa melihat ruang lingkup pembelajaran serta keahlian di lingkungan yang terbalik. Kegiatan belajar seperti ini memberikan kontribusi positif. Menurut (George, 2020) setiap rencana dengan cara bermain ular tangga tentang kesehatan yang telah diteliti terungkap ada peningkatan dalam pengetahuan post tes dan skor rektek, jadi dalam permainan juga menghasilkan meningkatkannya pembelajaran kesehatan. Perubahan sosial dengan memberikan pendidik dan pengertian tentang pentingnya memastikan siswa kompeten dalam menggunakan perangkat teknologi sosial itu mendorong peserta dalam berinteraksi secara sosial maupun akademis agar siswa menjadi pelajar mandiri.

Dalam kategori kelayakan, aspek hasil dari ahli materi memperoleh kualifikasi cukup layak. Aspek dari kedelapan tersebut diantaranya Kesesuaian antara materi dan tujuan pembelajaran, Aktualitas penyajian materi, Kecukupan jumlah soal, Kelengkapan cakupan soal, Tingkat kesulitan soal 
sesuai materi, Variasi soal, Kejelasan uraian evaluasi serta umpan balik evaluasi. Permasalahan ini mampu diselesaikan dengan temuan dari (Berrett, 2017) yang menyarankan bahwa Timez Attack dapat menjadi pilihan instruksi dengan bantuan teknologi dalam peningkatan kelancaran fakta perkalian siswa usia dasar.

Dalam kategori kelayakan, aspek hasil dari motivasi belajar siswa memperoleh kualifikasi layak. Pada aspek butir angket nomor 7 adalah "Saya merasa tekun dalam menyelesaikan tugas setelah menggunakan media" dan mendapat persentase $75 \%$. Artinya terdapat $25 \%$ dari siswa merasa tidak tekun atau rajin dalam menyelesaikan tugas matematika meskipun menggunakan mdia yang dibuat. Guru dapat memberikan materi tambahan pada siswa ketika berada di rumah, agar siswa menajadi lebih tekun. Menurut (Heppen, 2012) mengambil kursus aljabar 1 yang signifikan dan berpengaruh terhadap prestasi aljabar peserta didik pada akhir kelas 8 dan berkemungkinan untuk berpartisipasi dalam urutan kursus lanjutan pada sekolah menengah. Namun, perolehan hasil belajar online dan offline juga mempengaruhi ketekunan peserta didik. Dalam hal ini telah diteliti oleh (Brown, 2018) bahwa pensil dan kertas memiliki perbedaan yang signifikan dan untuk latihan matematika secara online. Kelompok kohort dengan penggunaan pensil dan kertas terbukti lebih efektif. Motivasi mempunyai peranan yang sangat besar dalam belajar (Khoiriyah, 2019) Motivasi menumbuhkan energi yang tidak mampu menggerakkan seseorang untuk melakukan kegiatan yang mungkin akan menguras seluruh tenaga dan fikiran. Peserta didik yang memiliki motivasi belajar tinggi akan bergiat, bersemangat, ulet tangguh untuk menyelesaikan tugastugasnya.

Aspek butir angket nomor 14 yaitu "Pelajaran matematika yang bermanfaat bagi kehidupan saya" pada perolehan hasil persentase $75 \%$. Artinya terdapat $25 \%$ peserta didik belum merasakan manfaatnya pada kegiatan sehari-harinya. Dalam penilaian kebermanfaatan peserta didik mampu melakukan modifikasi hasil temuan dari (Dani, 2016) yang merumuskan Log data belajar dalam ruang pengetahuan (ALEKS mencakup informasi mengenai jumlah pembahasan yang dipraktikkan dan jumlah topik yang telah dikuasai peserta didik. Atribut turunan, yang merupakan rasio jumlah topik dikuasai dan jumlah topik dipraktikkan ditemukan menjadi prediktor nilai akhir dalam kursus matematika dasar. Kebermanfaatan dari pembelajaran dapat dinilai dengan suatu format yang jelas. (Feldman, 2018) telah meneliti tentang efek penerapan berbasis kinerja pemberian nilai matematika pada kelas dua. Penelitian ini memperoleh hasil yang menunjukkan bahwa penggunaan penilaian kinerja memungkinkan peserta didik memperoleh pengetahuan tentang konsep matematika dalam peningkatan kosakata matematika dan keterampilan komunikasi mereka penilaian otentik, penilaian berbasis kinerja, matematis tugas kinerja, penilaian kinerja.

Pada pernyataan nomor 16 yaitu "Pembelajaran matematika mampu munumbuhkan rasa semangat belajar" memperoleh persentase $68.7 \%$. Artinya terdapat $31.3 \%$ siswa belum masih belum memiliki rasa giat untuk belajar meskipun menggunakan media yang dibuat. Pada penemuan sebelumnya dipaparkan bahwa (Ali, 2016) juga telah melakukan penelitian yang hampir sama dengan kegiatan ini yaitu Pengembangan Media Pembelajaran Permainan Ular Tangga pada Pembelajaran Matematika. Penelitian ini menggunakan metode yang diadaptasi dari Dick dan Carry. Dari hasil penelitian dan pengembangan ini diharapkan dapat dijadikan sebagai salah satu sumber belajar siswa melalui media permainan ular tangga serta penelitian lanjutan dengan mengembangkan media permainan ular tangga dalam bentuk elektronik.

Pada penelitian ini menghasilkan sebuah kegiatan bermain untuk menumbuhkan motivasi siswa dalam belajar menjadi meningkat melalui permainan kelompok namun mempunyai tujuan perorangan. Menurut (George, 2020) permainan ular tangga menunjukkan peningkatan dalam pemahaman dan praktek belajar siswa. Perbedaan dari penelitian yang telah dilakukan yaitu dari sisi materi dan penempatannya, jika pada umumnya memberikan soal atau materi terdapat pada papan permainan ular tangga secara langsung sedangkan penelitian ini melakukan pemisahan antara soal, dan motivasi yang 
akan memudahkan siswa belajar. Kemudian penelitian ini akan dengan mudah merubah soal sesuai materi karena soal terpisah dengan papan permainan sehingga memudahkan pendidik untuk tetap menggunakan media permainan ini dalam berbagai macam materi belajar lainnya. Ditengah pandemic ini dapat digunakan dengan cara bermain Bersama orang tua atau saudara dirumah agar orang tua juga dapat mengawasi proses belajar siswa itu sendiri. Dalam penelitian yang di paparkan (Ali, 2016) juga telah melakukan penelitian dan pengembangan yang hampir sama dengan penelitian yaitu Pengembangan Media Pembelajaran Permainan Ular Tangga pada Pembelajaran Matematika Materi Pecahan Kelas V SD dalam penelitian ini produk yang dihasilkan berupa media elekronik. Selain itu ada cara lain untuk menumbuhkan semangat belajar siswa. (Gu, 2017) Pembelajaran online menuntut siswa untuk mengatur sendiri proses pembelajaran mereka dan mempertahankan motivasi mereka untuk mencapai tujuan pembelajaran mereka, sama halnya dengan pembelajaran dengan permainan. Bila anak sudah kecanduan akan hal games online (Nugroho, 2020) maka akan menyurutkan semangat belajarnya dan akibatnya akan berdampak pada prestasi belajar di sekolah. Sebenarnya bukan masalah besar apabila anak di berikan sebuah gadget namun dengan bimbingan dan pengawasan dari orang tua agar di gunakan dengan semestinya.

\section{SIMPULAN}

Media ini merupakan wadah yang diperuntukkan bagi siswa kelas 2 SD yang mampu menumbuhkan motivasi belajar terhadap matematika sejak dini melalui media ini juga dilengkapi dengan soal motivasi yang akan terus memberikan kesadaran siswa tentang pentingnya belajar matematika. Perlunya dorongan dari pendidik dan juga keluarga agar dapat memperhatikan siswa bermain dengan game ketepatan dadu ini. Teknik pengembangan melalui media membuat game ketepatan dadu matematika dengan wadah plastik berbentuk persegi dan membutuhkan tempat dengan penutupnya. Data pengujian pada motivasi siswa tersebut, memperoleh hasil akhir yang cukup tinggi memotivasi siswa. Pengolahan hasil yang telah diolah terjadi data dan pengolongan yang sudah ditentukan, dapat terlihat bahwa media Permainan Ketepatan Dadu Matematika yang telah dikembangkan termasuk dalam kriteria dapat digunakan dalam kegiatan proses pembelajaran dan mendapatkan motivasi yang bagus dalam menjalankan proses media ini, sedangkan penggunaan media ular tangga dengan hasil permainan nyata menggunakan papan dapat dimainkan secara langsung. Permainan ini dapat dijadikan media elektronik di era digital, tetapi dalam penelitian saat ini yang dikembangkan ialah melalui permainan secara nyata sebab sekolah lebih membutuhkan yang dapat menunjang kreatifitas anak dan mudah digunakan.

\section{DAFTAR RUJUKAN}

Ali, Mochammad Sofyan. (2016). Pengembangan Media Pembelajaran Permainan Ular Tangga pada Pembelajaran Matematika Materi Pecahan Kelas V SD. Skripsi. Program Studi S1 Pendidikan Guru Sekolah Dasar, Jurusan Kependidikan Sekolah Dasar dan Prasekolah, Fakultas Ilmu Pendidikan Universitas Negeri Malang.

Berrett, Andrew N. and Nari J. Carter. (2017). Imagine Math Facts Improves Multiplication Fact Fluency in Third-Grade Students. J Behav Educn 27:223-239.

Brown, Amy Katherine. (2018). How Does Online Practice In A Public, Middle School Mathematics Classroom Affect Mathematical Understanding?. Dissertation. Trevecca Nazarene University. ProQuest LLC (2018) 10784729.

Dani, A., \& Nasser, R. (2016). Use of Intelligent Tutor in Post-Secondary Mathematics Education in the United Arab Emirates. Turkish Online Journal of Educational Technology-TOJET, 15(4), 152-162.

Fatoni, Fatkhul. (2016) Peningkatan Motivasi Belajar Matematika Melalui Strategi Team Game Tournament Dengan Media Cartoon Game Pada Siswa Kelas 2 MI Muhammadiyah Program 
Khusus Kartasura Tahun Ajaran 2015/2016. Skripsi thesis, Universitas Muhammadiyah Surakarta.

Feldman, Lexie P. (2018). Using Performance Assessments to Improve Number Sense in Second Grade Mathematics: An Action Research Study. Dissertation. Virginia Polytechnic Institute and State University. ProQuest LLC (2018) 10838952.

Feng, M., Roschelle, J., Mason, C., \& Bhanot, R. (2016). Investigating Gender Differences on Homework in Middle School Mathematics. Grantee Submission.

Fischer, U., Moeller, K., Cress, U., \& Nuerk, H. C. (2013). Interventions supporting children's mathematics school success: A meta-analytic review. European Psychologist, 18(2), 89.

George, G. (2020). The Effectiveness of Snake and Ladder Game Based Health Education On Healthy Practices Among Primary School Children-A Quasi Experimental Study. Review of General Psychology, 14(2), 113-121.

Gu, Peidi. (2017). Promoting Students' Motivation and Use of SRL Strategies in Online Mathematics Learning. Dissertation. University of Kansas. ProQuest LLC (2017) 10285507.

Handoko, Didin. 2017. Pengembangan Media Pembelajaran Play Dough Badut Dalam Pembelajaran Matematika Materi Menghitung Jumlah Sudut Segi Banyak Pada Siswa Kelas IV Madrasah Ibtidaiyah Darussalam. PPPPTK Matematka. Prosiding Seminar Nasional Pendidikan Matematika Ke-5 (SeNdiMat V). Hal 155-164.

Heppen, J.B., Walters, K., Clements, M., Faria, A., Tobey, C., Sorensen, N., and Culp, K. (2012). Access to Algebra I: The Effects of Online Mathematics for Grade 8 Students. (NCEE 2012-4021). Washington, DC: National Center for Education Evaluation and Regional Assistance, Institute of Education Sciences, U.S. Department of Education. 1-18.

Ichinose, Cherie and Martin Bonsangue. (2016). Mathematics Self-Realted Beliefs and Online Learning. California State University, Fullerton. TLAR, Volume 21, Number 1. 55-70.

Israel, Oginni 'Niyi. (2015). Effects Of Mathematics Innovation And Technology On Students Performance In Open And Distance Learning. Original scientific paper UDK: 37.025. DOI: 10.17810/2015.24. 66-75.

Kanprao, C., \& Naeprakhon, W. (2020, March). The development of thai language reading skills by using snake-ladder-game for primary 1 students of demonstration school of suan sunandha rajabhat university. In INTERNATIONAL ACADEMIC MULTIDISCIPLINARY RESEARCH CONFERENCE IN LUCERNE 2020 (pp. 185-188).

Khoiriyah, Nikmatul. (2019). Pengaruh Ulangan Harian Terhadap Motivasi Dan Prestasi Belajar Siswa Matapelajaran Matematika Di SDI Miftahul Huda Plosokandang Kedungwaru Tulungagung. Skripsi. Jurusan Pendidikan Guru Madrasah Ibtidaiyah, Fakultas Tarbiyah Dan Ilmu Keguruan, Institut Agama Islam Negeri (IAIN) Tulungagung.

Muzdalipah, Ipah dan Eko Yulianto. (2015). Pengembangan Desain Pembelajaran Matematika Untuk Siswa SD Berbasis Aktivitas Budaya Dan Permainan Tradisional Masyarakat Kampung Naga. Jurnal Siliwangi Vol. 1. No.1. Nov. 2015. Hal 63-74.

Nugroho, Muhammad Taufik. (2020). Analisis Games Online Pada Motivasi Belajar Siswa Kelas Atas Di SD IT Nur Hidayah Surakarta. Skripsi. Universitas Muhammadiyah Surakarta.

Nurhasanah, Isnaini U., Abdul Asib and Ngadiso. (2017). Dice Game: Enhancing Young Learners' 
Vocabulary Mastery In Learning English. 2017 International Conference on Education and Science (ICONS 2017)

Sahito, Zafarullah. (2019). Job Satisfaction And The Motivation Of Teacher Educators Towards Quality Education. Dissertations. Universities Of Sindh, Pakistan.

Strohmyer, Daniel. (2016). Student Perceptions of Flipped Learning in a High School Math Classroom. Dissertations. Walden Universitty.

Suwarni, S. dan Sunarti. (2016). Peningkatan Minat, Motivasi, Dan Prestasi Belajar Ips Melalui Media Gambar. Seminar Nasional Universitas PGRI Yogyakarta 2016. ISBN 978-602-73690-6-1. 591768.

Suyono dan Hariyanto. (2011). Belajar dan Pembelajaran. Bandung: PT Remaja. Rosdakarya Offset.

Ufer, S., Reiss, K., \& Mehringer, V. (2013). Sprachstand, soziale herkunft und bilingualität: Effekte auf facetten mathematischer kompetenz. Sprache im fach-sprachlichkeit und fachliches lernen, 167184. 